\title{
14 Fans and fams
}

\section{Experience and belonging aboard a cruise ship music festival}

\author{
David Cashman
}

\section{Introduction}

Imagine the excitement of being at an outdoor rock festival with your favourite band or genre. Think of the smells and sights and sounds of being front and centre a few feet from the stage where metal band Cannibal Corpse is shredding. You feel the vibrations of the subs in the pit of your stomach. The light show illuminates musician after musician, audience member after audience member. You are there with some of your best friends. But it is muddy from earlier rains, and you are sleeping in a tent. You have to queue for drink and food, which is expensive. And the less said about the toilets, the better. Now imagine that same festival, but this time you are sleeping in a small but luxurious room. You have a room steward to make your bed each night and to bring you room service at your whim. Food is plentiful and included in the festival admission. There are a multitude of bars and staff to wait on you. You have more than one stage and can move between your favourite acts. The cost of the festival is reasonable and all inclusive. You still have your friends there, but you meet strangers that become friends and call you their family. You have a much greater chance of meeting your musical idols. You still get to listen to Cannibal Corpse, but this time you do it from a jacuzzi at the side of the stage.

Sounds good, doesn't it? Such experiences are common to thousands of festivalgoers who attend popular music festivals on cruise ships. Dozens of these festivals now ply the waterways of the world servicing fans of bluegrass, metal, indie rock, and a plethora of other genres. There is an intense feeling of camaraderie, and participants refer to each other and the artists as "ship fam". This intense feeling of belonging is somewhat at odds with the location, which is a mobile geography and a non-place where it is not physically possible to "belong".

There are three concepts of import to successful music festivals on cruise ships. First, cruise festivals celebrate a specific but wide variety of music genres, including alternative rock (The Rock Boat); metal (70,000 tons of Metal, Monsters of Rock); dance music, also known as EDM (Holy Ship!, Mad Decent Boat Party); country music (The Country Music Cruise, Cruisin' Country); jazz (Blue Note at Sea, The Jazz Cruise); Soul (Soul Train 
Cruise); and more. Other festivals celebrate a particular band, such as the KISS cruise, the Kid Rock cruise, or the Weezer cruise. Festivalgoers are passionate about the music or band and understand and celebrate the cultural signifiers and performance conventions of the genre. Second, the cruise environment is a desirable place to hold a music festival. Many of the issues that plague promoters of land-based festivals, such as accommodation, security, the provision of food and drink, the construction of performance spaces, technical equipment, and staff, are already present on cruise ships. Cruises are regarded both by general cruise tourists (Hosany \& Witham, 2010; Huang \& Hsu, 2009; Hung \& Petrick, 2011; Kwortnik, 2008) and interviewed festivalgoers as a luxurious and desirable holiday. Third, interaction between festivalgoers and also between festivalgoers and musicians within this hedonistic, intense, and neotribal (Maffesoli, 1996) festival experience results in a constructed and artificial closeness and sense of belonging. Participants in this research reported staying in contact with fellow "ship fam", sometimes meeting up between cruises, attending land-based concerts, and generally experiencing a warm and unusually intimate experience with fellow cruise passengers during the festival.

This chapter considers how belongingness is co-opted by festival organizers to create a socially and commercially successful ocean-going festival experience. These festivals have no need to interact with the region or culture in the manner of a land-based festival but can focus entirely on the music, on the musicians, and on the festivalgoers and their temporary society. These festivals are of increasing significance on the world festival circuit, providing employment to musicians, engaging fans, and opportunities to belong, if only for a few days, to a collective dedicated to music and experience. Data were drawn from a series of nine interviews undertaken in 2016 augmented by an open-ended survey, which captured 129 respondents. This sample incorporated 19 different festivals, including The Rock Boat (58\%), 70,000 Tons of Metal (23\%), Ships and Dip (10\%), Live Loud (6\%), Rombello (6\%), and Mad Decent Boat Party (5\%). These data were analysed using a grounded theory methodology. The research finds that festival organizers co-opt the mobile geography of the cruise ship and the sensory tourism of the festival to construct a purposeful experience that creates a fabricated sense of belonging and camaraderie. This hyperreal belonging makes return visits more likely, thereby increasing the financial viability of the enterprise.

\section{The tourist experience of cruise festivals}

Cruise festivals combine two tourist models: cruise tourism and festival tourism. Cruise tourism is one of the success stories of the tourism industry. From 2000 until 2010, passenger numbers have grown at $8 \%$, more than three times the growth rate of international arrivals on air transport (Clancy, 2017: 43), though this has slowed somewhat since (Cruise Line International 


\section{David Cashman}

Association, 2016: 7). Cruise ships generate enormous profits, mainly from onboard revenue (Becker, 2006; Vogel, 2017). Onboard revenue includes the costs of cruising not contained in the ticket price, notably gambling, consumption of alcohol, and spa treatments. A cruise ship has been likened to a cocoon (Vogel, 2004), a mobile tourist enclave (Weaver, 2005), and an extended "tourist bubble" (Jaakson, 2004). These models are variations on the steel capsule of the cruise ship, which firmly defines the tourist area of the ship and the area outside the ship: ports and ocean. By creating a solid boundary point, tourists' attention is pointed inwards, and onboard revenue thrives. While little research has been undertaken on the social and cultural aspects of cruise ships, there is general agreement they are postmodern and hyperreal tourism products (Kulhanek, 2012; Vogel \& Oschmann, 2013; Williams, 2012) and consequently encourage guests to playfully engage with their surroundings (Feifer, 1985). This encapsulation and the resultant onboard revenue is the key to the success of the cruise industry.

Festivals on cruise ships sit between several established paradigms. They are clearly music festivals in that they celebrate a genre or a person; however, there are several conflicting models for festivals (Getz, 2010) all of which contribute to our understanding. Falassi (1987: 2), for example, describes festivals in anthropological terms as "a sacred or profane time of celebration, marked by special observances", a definition that clearly applies to cruise music festivals. To Pieper (1965), only religious celebrations are festivals. There are certainly processes akin to religious ceremony in cruise festivals, such as ritual, worship, and celebration. Arcodia and Robb (2000) note that festivals are public, celebratory, and embedded in community. The community of the "ship fam" is central to cruise festivals. However, most festivals are strongly connected with and invested in place (De Bres \& Davis, 2001; Derrett, 2003; Lau \& Li, 2015; McClinchey \& Carmichael, 2010; Quinn, 2003) to the extent of "eventrification" of geographical place (Jakob, 2013). Cruise ships are placeless festivals, existing only within the placeless (Augé, 1992; Relph, 1976) and unnamed ocean. MacLeod's (2006) work on placeless festivals, which she calls "postmodern festivals" or "post-festivals" is pertinent. To the festival attendees, geographical place is less relevant than engaging with the experience.

The experience between festivals is remarkably similar. They begin with pre-parties the day or so before the festival. The ship will be boarded from about midday after the previous passengers disembark and will depart at about $5 \mathrm{pm}$. Once at sea, a routine establishes itself. Performances commence at $10 \mathrm{am}$ in various venues around the ship, especially the main theatre and a large stage on the lido deck. They may dock in a port, one of the specially altered islands leased by the cruise line, or may stay at sea. In their pursuit of abandon, festivalgoers may consume large amounts of alcohol and participate in traditional cruise ship activities such as belly-flop competitions and bingo (albeit with a rock and roll twist). There are theme nights where attendees dress up in pre-organized costumes. Performances end a few hours 
before sunrise, and the last stalwart partiers go back to their cabins before to crash for a few hours before awakening to do it all again.

Cruise festivals tend to be comparatively small and intimate, with numbers limited by the physical capacity of the cruise ship, often around 2,000 for midrange ships. Participants comment positively on this aspect, describing "All the awesomeness of non-stop music, with none of the hassles of huge crowds, mud, port-a-potties, camping”, and

No worries about noise bothering the neighbours, no curfews, no worries about drinking since your cabin is so close, all of your friends and musician friends are close by, food is ready for you any time of the day or night to easily grab something on the run if there's a show to get to.

Festival interactions occur within the magical tourist space of the cruise ship. This encapsulated space functions as the delineator of festival space, as a barrier to casual departure, as luxurious space, and as the container for an experience.

\section{Theory}

Cruise music festivals are a relatively new model of tourism and have not yet attracted great amounts of research. However, there are several relevant areas that shed some light. Belongingness sheds light on the processes of onboard community. Sensory tourism considers the way that cruise tourists interact with the festival. Finally, experiential tourism considers the actual experience of the festival.

Belongingness is a key human motivation (Baumeister \& Leary, 1995). It is the third aspect of Maslow's hierarchy of needs, indicating the belief that one cannot achieve self-esteem and self-actualization without social belonging. Lee and Robbins (1995), basing their work on Kohut (1971) and Patton et al. (1982), argue that belongingness is composed of three incremental aspects companionship, affiliation, and connectedness (Lee \& Robbins, 1995: 232). Companionship is the relationship with close family and is the first aspect of belongingness. Affiliation is about peer relations while growing up. Connectedness refers to the adult feelings of being "human among humans" (ibid: 233). Cruise ship festivals encourage this sense of social belonging via the adoption and promotion of the concept of the "ship fam". The stoking and manipulation of Lee and Robbins' three aspects are of considerable import to the aesthetic and financial success of cruise ship music festivals.

The friendships that develop deeply and quickly between festival participants, as well as participants and musicians, with egalitarian and community implications, can be understood within the model of communitas. "Communitas", a concept proposed by Turner (1969, 1974), involves a close, temporary bonding generated by shared experience. Many scholars have noted the relationship of festivals, liminality, and the generation of 


\section{David Cashman}

communitas (Arcodia \& Whitford, 2006; van Heerden, 2009; Rutherdale, 2008). This became a key concept within tourism studies (Cohen, 1979; Duffy et al., 2011; Franklin, 2003; Wang, 1999; Yarnal \& Kerstetter, 2005). Urry and Larsen (2011: 11) note that "an intense bonding communitas" is experienced by a tourist who finds him/herself in an "anti-structure ... out of time and place - conventional social ties are suspended". Connell and Gibson (2003: 228) further note that

music tourism sub-cultures have emerged around the tours of particular artists, with groups of highly committed fans (even "groupies"), who follow performers around from concert to concert, even generating a sense of communitas through shared experiences, fan clubs and traditions maintained on-tour.

This focus on the collective experience of cruise festivals can be also contextualized within Maffesoli's (1996; Maffesoli \& Foulkes, 1988) concept of "neo-tribalism". Maffesoli argues that as the social institutions of modernism have transformed into those of postmodernism, their ability to fuse large groups of people towards a common goal has been lost, replaced by small groups bonded by common experience, emotions, and aesthetics. Certainly, festivalgoers share a common aesthetic desire for the music celebrated by the festival. Words and phrases used to describe the "ship fam" are affectionate: music lovers, friendly, nice, broad demographic, family, international, partiers, like-minded, and there to have a good time.

Cruise festival tourism is a product of sensory tourism. Humans broadly construct their experience through interpreting the world, based on sensory input. Some of the senses have received significant academic attention, including sight (Franklin, 2001; Gillespie, 2006; Urry, 1990, 2008), taste (Cohen, 2004; Kivela \& Crotts, 2006; Richards, 2002), and, to an extent, smell (Dann \& Jacobsen, 2003). However, the traditional senses of touch and hearing (and non-traditional senses such as chronoception and thermoception) have received little study. As Gottschalk and Salvaggio (2015: 11) note, "it is not sufficient to 'just add' smell, touch, taste, or chronoception to the panoply of senses one attends to when conducting mobile ethnography; the challenge is to understand their dynamic interplay". While the interplay between the various senses is of import to this discussion, the process of sound as a semiotic symbol, as a device for engaging tourists, and as promoting a profitable tourism product is of particular importance. The constructed and humanly fabricated space of a cruise ship is devoid of meaning until culture is poured into it by the cruise line and co-opted by the festival organizers. It is this inherent meaninglessness meaning that provides cruise operators with the opportunity to musically enculture the space. In so doing, they focus their clients' attention on the music, the "ship fam", and the experience without the distraction of engaging with the specific geography in which tourists find themselves. 
Hyperreality theory, pioneered by Umberto Eco (1987) and Jean Baudrillard (1994) posits that there exist instances of consciousness whereby an individual is unable to perceive the difference between reality and fabrication. The tourism industry regularly co-opts this postmodern idea to create engaging experiences that permit participants to playfully bend the nature of reality. As noted, cruise ships are prime examples of hyperreality (Kulhanek, 2012; Vogel \& Oschmann, 2013; Williams, 2012) in that they are fabricated environments bearing the illusion of social and cultural reality. The Royal Caribbean ship Voyager of the Seas

is a classic example of simulacrity and hyperreality, the loss of authenticity and the becoming real of what was previously a simulation, artefacts from a bygone era becoming part of the décor, with designers recycling them as sculpture and other art. Thematic elements, including photographs, ship's compasses and navigational equipment are pinned to the wall. Voyager of the Seas has a theatre called La Scala, it also has an art collection valued at some $\$ 7.5$ million and a shopping mall, the Royal Promenade, modelled on Burlington Arcade.

(Williams, 2012: 195)

Hyperreality in tourism utilizes and informs the concept of experience. The cruise industry generally and the cruise music festival business specifically are in the business of staging experiences. Early models for tourist experience included the SERVQUAL model (Parasuraman, Berry \& Zeithaml, 1991; Parasuraman et al., 1985, 1988) and Bitner's Servicescape model (1992); however, the most broadly influential model is that of Pine and Gilmore $(1998,1999,2011)$. Pine and Gilmore state that there are two axes for participation in the experience economy. The first is that of participation, defining how audiences affect the touristic performance. In passive participation, guests do not directly affect the performance, but active participation means that they do. The second axis, connection, discusses the connection of the guest to the performance. An absorbed guest is occupied by a touristic performance from a distance, but an immersed guest physically becomes a part of the touristic performance. Combining these axes results in the realms of an experience. An experience enjoyed ...

- ... from a distance (absorbed connection) without being affected by guests (passive participation) is entertainment;

- ... from a distance (absorbed connection) but directly affected by guests (active participation) is educational;

- ... by being immersed (immersed connection) without being affected by guests (passive participation) is aesthetic;

- . . . by being immersed (immersed connection) but directly affected by guests (active participation) is escapist. 


\section{David Cashman}

In the centre is the "sweet spot", representing the richest of possible experiences. To attain the sweet spot, all aspects must be equally weighted and evident. Pine and Gilmore (2011: 59) state that "to design a rich, compelling and engaging experience, you don't want to incorporate only one realm". All aspects must be considered in designing an experience. Pine and Gilmore (1998: 102-105) further note that an experience should be themed, should harmonize impressions with positive cues, should eliminate negative cues, should mix in memorabilia, and should engage all five senses. The geographical space of hyperreal spaces is entirely constructed. Humans turn space into place by naming it (Relph, 1976). If this is the case, cruise ships are constructed and are mobile geographies in a way like no other. They are enormous, with the largest the formidable Royal Caribbean Oasis-class. Populated by humans, they are named in the traditional nautical fashion (port, starboard, aft, stern), but also by location, for example, the Blue Sapphire Lounge, the lido deck, the main restaurant. Yet these geographies move from place to place in a manner like no other human community, among the unpopulated and largely unnamed oceans. Thus, as well as being geographical places by being named, they are also not places by virtue of being unfixed. Two scholars in particular discuss this. Relph (1976) talks of the concept of "placelessness", a process by which place is experienced "inauthentically" by the concept of "kitsch" - an uncritical acceptance of presented values. Augé (1992) discusses the concept of non-place (non-lièges), anthropological spaces of transience. One of the participants said that she

couldn't think of anything better than seeing some of my favourite bands in the middle of the ocean with people who loved them as well. And cocktails.

This simultaneous duality of place means that ships can be engaged with by festival participants, but the focus is turned inward towards the festival, because there is no "outside" with which to engage.

\section{The festivals}

The experience of a cruise festival falls well within a Pine and Gilmore experience. It is clearly themed according to the focus of the festival. Theme nights are incorporated into the event. Musical memorabilia and souvenirs are available onboard, photos are taken by ship photographers and participants, and autograph seekers are catered to. All five traditional senses are engaged almost to the point of sensory overload. Moreover, the careful planning of the festival and the inclusion of the four realms of the experience place it very close to the sought-after sweet spot.

Because of the careful and experiential planning of the festival, the generation of belongingness and communitas is particularly strong in these oceanborne festivals. Festival planners purposely design it to be so. Music festivals 
often generate communitas of their own accord, but by hosting a music festival on a ship, the festival has no distracting geographical place outside the festival to distract from the actual festival. Participants noted that the environment of the ship was more amenable to the construction of friendship. As one participant forthrightly put it:

Holy fucking shit! A cruise ship is the optimal environment for a music festival. First off, you're safe: there's a doctor on board and tons of staff that care about your well-being. If you're feeling sick, you can go back to your cabin and rest. If you're hungry, you can walk five minutes and grab free food. If you're dehydrated, you go to a water station and grab a glass of water. Outdoor festivals have none of those things, and if they have those things, they're expensive, inconvenient, or difficult to access. A cruise ship is so, so insanely safe. A cruise ship is also great for noise concerns. No complaints from local residents or police, because you're on an ocean. A cruise ship festival is also all-inclusive. You never have to worry about getting back to your hotel, or finding food, or making public transportation before the show ends. Everything exists on the cruise ship, and it's incredibly peaceful.

The temporary inhabitants of the liminal space within a cruise ship are encouraged to "dress differently, eat and drink differently, sleep differently, act differently, play differently, and feel differently" (Yarnal \& Kerstetter, 2005: 370). Festivalgoers certainly do all these things. They undertake fancy dress, outfitting themselves as giant pigs or pieces of fruit, or jockeys astride a horse. They consume large quantities of alcohol and excellent food. They stay up until the bands stop playing and wake late to do it all again. One participant described it as

the most atypical experience of my life. I'd wake up at 1PM, crawl to the buffet and snag a disgusting amount of pizza and return to my room. Chill out with the boyfriend, chill out with friends, and just enjoy the time on the boat. Then, an event would start around 5PM, and we'd check that out. With great music starting at 6PM, we'd party for a few hours, grab some food, party, grab some food, and repeat all of that until 5AM. Also scattered throughout there: drinking heavily, costume changes, twerking, and generally weird stuff.

Festivalgoers act, feel, and play completely differently to how they do on land.

Fans are also likely to engage with star performers at a cruise festival. Musicians are encapsulated in the festival experience, enclosed in a placeless space for the duration of the cruise rather than being whisked away at the end of their show; the band that fans saw onstage one night is lining up at the breakfast buffet the next morning. One attendee reported having 


\section{David Cashman}

dinner with Ed Robertson, lead singer, guitarist, and songwriter of Barenaked Ladies. Another guest recounted that

Wintersun's first performance in the indoor arena . . . brought me to tears, it was so technically brilliant. Here I was, the mother, crying in the pit. I got to tell Jari [Mäenpää, singer and guitarist] that too and he was touched. He took my hand and put it on his heart and said "That means so much to me. Thank you".

These encounters are described as "parasocial" by Horton and Wohl (1956). This term describes the relationship of fans to stars that is seemingly intimate but actually mediated by television, radio, or the distance of the performance hall. Certainly this relationship is mediated; an interviewed festival organizer revealed that in many festivals, mingling with the guests was written into musicians' contracts. However, to participants, it seems natural and authentic. One respondent recounted

sitting around in a hallway with members of Collective Soul, other bands and other fans singing oldies while someone played guitar. The chance to sit next to my favourite rock stars and sing songs was a dream come true.

I am not suggesting that artists do not react genuinely to fan encounters; clearly they do. However, fan-artist meetings in a fabricated and hyperreal space that neither can escape from, and in a system that mandates interactions between the two groups, is a hyperreal encounter. By promoting and managing parasocial encounters between star performers and festivalgoers, organizers create an unusual level of intimacy between the two groups in the pursuit for the construction of belongingness.

A further level of belongingness is manifest in the construction of "ship family", usually abbreviated to "ship fam". After the music, participants regarded the family-like intimacy within the festival participants as of great import. Many festivalgoers that met on the ship, or perhaps shared a cabin, maintained contact between festivals by meeting for concerts (if possible), or through social media. One festivalgoer reported,

With the ship-based festivals, you are on the boat with all these people. You may not see them all, but they're there and you can run into random people and know you'll see them at some other point. I think there's a stronger camaraderie with the ship-based festivals.

Festivalgoers contrasted the more intense sense of belonging in a cruise festival and the relative anonymity of a larger festival. One participant noted:

I think I'm getting a bit too old for regular music festivals. By the time the boat party was over, everybody knew each other. Everybody was 
friends on the boat whereas you don't really get that at land-based music festivals anymore. Obviously it was a lot smaller, so there was only about 2.000 people on the boat as well. So after being on there for four or five days you kind of knew everyone's faces.

\section{Implications and concluding remarks}

As with hyperreal tourism products, there is a disconnect between fabrication and authenticity in cruise festivals. On the one hand, the festival occurs in an entirely fabricated and hyperreal geography. Encounters between fans and star performers are managed and constructed. The relationships between festivalgoers and between festivalgoers and star performers are temporary and parasocial. Yet the experience is perceived as "real" and "authentic". Fans (and potentially musicians) feel that these temporary relationships are real enough to call each other "family". Festivalgoers seemingly "belong", but there is no place and no one to belong to.

Belongingness and connectedness are key to tourism. Many scholars (such as Cohen, 1979; Crompton, 1979; Dann, 1977; Pearce, 1993) have written on how tourism enhances family and connectedness. However, increasingly, tourists are using different methods to achieve a sense of belonging (Gössling et al., 2016; Krohn, 2012). The production companies that run these festivals are well aware of the importance of the sense of belonging and connectedness to the financial and aesthetic success of cruise festivals. They do whatever they can to ensure that festivalgoers achieve this. They mandate interaction between fans and musicians. They purposely construct a liminal space that is separate from everyday space, where festivalgoers undertake unusual activities such as dressing up in wild costumes, undertaking cheesy cruise ship events, and partying non-stop from $10 \mathrm{AM}$ until 4 AM.

Cruise music festivals construct a facsimile of belongingness so guests will feel engaged and empowered by the temporary society of the festival. This becomes obvious upon a consideration of Lee and Robbins' (1995) three aspects of belongingness: companionship, affiliation, and connectedness. Companionship (the relationship with close family) is overtly fabricated by the employment of terms such as "ship fam" and "family" by both festivalgoers, organizers, and star performers throughout the festival. Festivalgoers spoke constantly of their ship family during interviews. Affiliation (peer relations while growing up) is fabricated by the performance of music from the youth of participants: the median ages of festivalgoers on The Rock Boat were 36-40, metal festivals were 31-35, and EDM festivals were 21-25. The engagement of music from their youth (even if that was just a few years ago) allows festivalgoers to regress into this time and, by proxy, their fellow festivalgoers become their teenage peers. The additional engagement of childish and unrestrained behaviour adds to this feeling of temporal disconnect. Finally, connectedness (the adult feelings of being "human among humans") 
is created by the proximity of humans sharing an intensely sensory experience on the dance floor, while eating, while engaging in hero worship, and the other aspects of the festival. It is hard to get away from other humans while attending the festival. The resulting belongingness is, in a way, hyperreal and facsimile, a fabrication and construction of real belongingness. Yet it feels very real to the participants.

The net result of this fabricated belongingness is repeat visits: an annual pilgrimage - a term Turner may have found interesting - to attend the festival next year with fellow "ship fam". Slightly more than two-thirds of the sample attended more than one cruise festival, with the average being five festival attendances. One respondent reported attending 14 festivals. Belongingness, while it creates an engaging and memorable festival experience, also ensures the financial viability of the festival. Some festivals, among them Holy Ship!, are now so successful they are having to schedule multiple annual sailings.

By holding festivals on a placeless cruise ship, by managing star/fan interaction, and by creating a strong sense of communitas, cruise festival organizers tap into the need for people to belong to a community. In this case, it is a community brought together by love of a genre of music or of a particular artist. Perceived as authentic and real, this sense of belonging occurs in a fabricated and hyperreal fashion in a fabricated and hyperreal environment. Participants are regarded as "family", yet they are almost all strangers brought together perhaps once, perhaps annually. The entire tourist experience is a temporary and ephemeral community lasting only a few days before scattering across the world. Yet this managed belongingness is seductive and personal. It creates festivals that are financially and aesthetically successful, encounters that are fabricated but perceived as genuine, and tourist experiences that are memorable. Despite the disconnect between the authenticity of the experience and the manufactured and fabricated reality, the festivalgoers do not complain. And they will return next year.

\section{Bibliography}

Arcodia, C. \& Robb, A. (2000). A future for event management: A taxonomy of event management terms. Events beyond 2000: Setting the agenda: Proceedings of conference on event evaluation, research and education, 154-160. Sydney, Australia.

Arcodia, C. \& Whitford, M. (2006). Festival attendance and the development of social capital. Journal of Convention \& Event Tourism 8(2): 37-41.

Augé, M. (1992). Non-lieux: Introduction à une anthropologie de la surmodernité. La librairie du XXe siècle. Paris: Seuil.

Baudrillard, J. (1994). Simulacra and simulation (S.F. Glaser, Trans.). Ann Arbor: University of Michigan Press.

Baumeister, R.F. \& Leary, M.R. (1995). The need to belong: Desire for interpersonal attachments as a fundamental human motivation. Psychological Bulletin 117(3): 497-529. 
Becker, B. (2006, October). Onboard revenue takes centre stage. International Cruise and Ferry Review: 17-18.

Bitner, M.J. (1992). Servicescapes: The impact of physical surroundings on customers and employees. Journal of Marketing 56: 57-71.

Clancy, M. (2017). Power and profits in the global cruise industry. In: R. Dowling \& C. Weeden (eds.), Cruise ship tourism, 2nd ed, pp. 43-56. Oxford: CABI.

Cohen, E. (1979). A phenomenology of tourist experiences. Sociology 13(2): 179-201.

Cohen, E. (2004). Tourism and gastronomy. Annals of Tourism Research 31(3): 731-733.

Connell, J. \& Gibson, C. (2003). Sound tracks: Popular music identity and place. London: Routledge.

Crompton, J.L. (1979). Motivations for pleasure vacation. Annals of Tourism Research 6(4): 408-424.

Cruise Line International Association. (2016). 2017 cruise industry outlook. Press Conference Presentation. Retrieved from www.cruising.org/docs/default-source/ research/clia-2017-state-of-the-industry.pdf.

Dann, G. (1977). Anomie, ego-enhancement and tourism. Annals of Tourism Research 4(4): 184-194.

Dann, G. \& Jacobsen, J.K.S. (2003). Tourism smellscapes. Tourism Geographies 5(1): 3-25.

De Bres, K. \& Davis, J. (2001). Celebrating group and place identity: A case study of a new regional festival. Tourism Geographies 3(3): 326-337.

Derrett, R. (2003). Making sense of how festivals demonstrate a community's sense of place. Event Management 8(1): 49-58.

Duffy, M., Waitt, G., Gorman-Murray, A. \& Gibson, C. (2011). Bodily rhythms: Corporeal capacities to engage with festival spaces. Emotion, Space and Society 4(1): 17-24.

Eco, U. (1987). Travels in hyperreality. London: Pan Books.

Falassi, A. (1987). Festival: Definition and morphology. In: A. Falassi (ed.), Time out of time: Essays on the festival, pp. 1-10. Albuquerque: University of New Mexico Press.

Feifer, M. (1985). Going places: The ways of the tourist from imperial Rome to the present day. London: MacMillan London Limited.

Franklin, A. (2001). The tourist gaze and beyond: An interview with John Urry. Tourist Studies 1(2): 115-131.

Franklin, A. (2003). Tourism: An introduction. London: Sage.

Getz, D. (2010). The nature and scope of festival studies. International Journal of Event Management Research 5(1): 1-47.

Gillespie, A. (2006). Tourist photography and the reverse gaze. Ethos 34(3): 343-366.

Gössling, S., Cohen, S.A. \& Hibbert, J.F. (2016). Tourism as connectedness. Current Issues in Tourism 21(14): 1586-1600.

Gottschalk, S. \& Salvaggio, M. (2015). Stuck inside of mobile: Ethnography in nonplaces. Journal of Contemporary Ethnography 44(1): 3-33.

Horton, D. \& Wohl, R.R. (1956). Mass communication and para-social interaction: Observations on intimacy at a distance. Psychiatry 19(3): 215-229.

Hosany, S. \& Witham, M. (2010). Dimensions of cruisers' experiences, satisfaction, and intention to recommend. Journal of Travel Research 49(3): 351-364.

Huang, J. \& Hsu, C.H.C. (2009). Interaction among fellow cruise passengers: Diverse experiences and impacts. Journal of Travel and Tourism Marketing 26(56): 547-567. 


\section{David Cashman}

Hung, K. \& Petrick, J.F. (2011). Why do you cruise? Exploring the motivations for taking cruise holidays, and the construction of a cruising motivation scale. Tourism Management 32(2): 386-393.

Jaakson, R. (2004). Beyond the tourist bubble? Cruise ship passengers in port. Annals of Tourism Research 31(1): 44-60.

Jakob, D. (2013). The eventification of place: Urban development and experience consumption in Berlin and New York City. European Urban and Regional Studies 20(4): 447-459.

Kivela, J. \& Crotts, J.C. (2006). Tourism and gastronomy: Gastronomy's influence on how tourists experience a destination. Journal of Hospitality and Tourism Research 30(3): 354-377.

Kohut, H. (1971). The analysis of the self. New York: International Universities Press.

Krohn, B.D. (2012). Social motivations for attending in event tourism. Athens Tourism Symposium. Athens, Greece.

Kulhanek, I. (2012). Hyperreality in post-tourism: An analysis of fun, space and the experience of "hyperreality" aboard Carnival's cruise ships. MA thesis. Vienna: Universität Wien.

Kwortnik, R.J. (2008). Shipscape influence on the leisure cruise experience. International Journal of Culture, Tourism and Hospitality Research 2(4): 289-311.

Lau, C.Y.L. \& Li, Y. (2015). Producing a sense of meaningful place: Evidence from a cultural festival in Hong Kong. Journal of Tourism and Cultural Change 13(1): 56-77.

Lee, R.M. \& Robbins, S.B. (1995). Measuring belongingness: The social connectedness and the social assurance scales. Journal of Counseling Psychology 42(2): 232-241.

MacLeod, N.E. (2006). The placeless festival: Identity and place in the post-modern festival. In: D. Picard \& M. Robinson (eds.), Festivals, tourism and social change: Remaking worlds, pp. 222-237. Clevedon: Channel View Publications.

Maffesoli, M. (1996). The time of the tribes. London: Sage.

Maffesoli, M. \& Foulkes, C.R. (1988). Jeux de masques: Postmodern tribalism. Design Issues 4(1-2): 141.

McClinchey, K.A. \& Carmichael, B.A. (2010). The role and meaning of place in cultural festival visitor experiences. In: M. Morgan, P. Lugosi \& J.R. Brent Ritchie (eds.), The tourism and leisure experience: Consumer and managerial perspectives, pp. 59-80. Clevedon: Channel View Publications.

Parasuraman, A., Berry, L.L. \& Zeithaml, V.A. (1991). Refinement and reassessment of the SERQUAL scale. Journal of Retailing 67(4): 420-450.

Parasuraman, A., Zeithaml, V.A. \& Berry, L.L. (1985). A conceptual model of service quality and its implications for future research. Journal of Marketing 49(4): 41-50.

Parasuraman, A., Zeithaml, V.A. \& Berry, L.L. (1988). SERVQUAL: A multiple-item scale for measuring consumer perceptions of service quality. Journal of Retailing 64(1): 12-40.

Patton, M.J., Connor, G.E. \& Scott, K.J. (1982). Kohut's psychology of the self: Theory and measures of counselling outcome. Journal of Counseling Psychology 29(3): 268-282.

Pearce, P.L. (1993). Fundamentals of tourist motivation. In: R.W. Butler \& D.G. Pearce (eds.), Tourism research: Critiques and challenges, pp. 85-105. London: Routledge. 
Pieper, J. (1965). In tune with the world: A theory of festivity. New York: Harcourt Brace.

Pine, J. \& Gilmore, J. (1998). Welcome to the experience economy. Harvard Business Review 76(4): 97-105.

Pine, J. \& Gilmore, J. (1999). The experience economy: Work is theater \& every business a stage. Boston: Harvard Business School Press.

Pine, J. \& Gilmore, J. (2011). The experience economy. Boston: Harvard Business Review Press.

Quinn, B. (2003). Symbols, practices and myth-making: Cultural perspectives on the Wexford Festival Opera. Tourism Geographies 5(3): 329-349.

Relph, E.C. (1976). Place and placelessness. London: Pion.

Richards, G. (2002). Gastronomy: An essential ingredient in tourism production and consumption? In: A. Hjalager \& G. Richards (eds.), Tourism and gastronomy, pp. 3-20. London: Routledge.

Rutherdale, R. (2008). Canada's August Festival: Communitas, liminality, and social memory. Canadian Historical Review 77(2): 221-249.

Turner, V. (1969). The ritual process: Structure an antistructure. Ithaca: Cornell University Press.

Turner, V. (1974). Pilgrimage and communitas. Studia Missionalia 23: 305-327.

Urry, J. (1990). The tourist gaze. London: Sage.

Urry, J. (2008). Globalising the tourist gaze. In: Tourism development revisited: Concepts, issues and paradigms, pp. 150-160. London: Sage.

Urry, J. \& Larsen, J. (2011). The tourist gaze 3.0. London: Sage.

van Heerden, E. (2009). Liminality, transformation and communitas: Afrikaans identities as viewed through the lens of south African arts festivals: 1995 - 2006. DPhil dissertation. Stellenbosch: University of Stellenbosch.

Vogel, M.P. (2004). Kreuzfahrt: Reisen im dreifachen kokon. Am Bord 5: 17-20.

Vogel, M.P. (2017). Economics of cruise shipping: The need for a new business model. In: R.K. Dowling \& C. Weeden (eds.), Cruise ship tourism, 2nd ed, pp. 124-137. Wallingford: CABI.

Vogel, M.P. \& Oschmann, C. (2013). Cruising through liquid modernity. Tourist Studies 13(1): 62-80.

Wang, N. (1999). Rethinking authenticity in tourism experience. Annals of Tourism Research 26(2): 349-370.

Weaver, A. (2005). Spaces of containment and revenue capture: 'Super-sized' cruise ships as mobile tourism enclaves. Tourism Geographies 7(2): 165-184.

Williams, A. (2012). Understanding the hospitality consumer. Oxford: ButterworthHeinemann.

Yarnal, C.M. \& Kerstetter, D. (2005). Casting off: An exploration of cruise ship space group tour behaviour, and social interaction. Journal of Travel Research 43(4): 368-379. 